\title{
EDUCAÇÃO E HEGEMONIA CATÓLICA NO BRASIL( 1870 a 1900)
}

\author{
Prof. Dr. Peri Mesquida*
}

\section{Resumo}

O presente estudo é o resultado parcial de uma pesquisa histórica na área da educação que, à luz de fontes primárias e historiográficas, procura identificar as agências e os atores sócio-históricos que, nas três últimas décadas do século XIX, ignoraram a educação ou dela se utilizaram para exercer influência política e religiosa sobre o conjunto da sociedade. Em particular, focamos as nossas investigações sobre as relações que se estabeleceram entre a Igreja e o Estado, nos últimos tempos do regime monárquico e os primeiros anos da República, levando em consideração as transformações que se operavam no modo de produção.

Palavras-chave: educação, igreja, capitalismo, fazenda, modo de produção.

\section{Résumé}

Cet étude est le résultat partiel d'une recherche historique en éducation qui, au travers de sources primaires et de sources historiographiques, cherche d'identifier les agences et les acteurs socio-historiques qui, dans la période de 1870 à 1900, ontignoré l' éducation ou se sont utilizés d'elle pour l'exercice de l'influence politique et religieuse sur l'ensemble de la société. D'une façon spéciale, nous conduisons notre recherche de façon à cerner les rapports entre l' église et l' état à la fin de la monarchie et pendant les premières années de la république, en nous rendant compte des transformations qui a subi le mode de production au Brèsil.

Mots-clés: éducation, église, capitalisme, fazenda, mode de production.

* Professor/Pesquisador do Programa de Mestrado em Educação da PUCPR

Colaboradoras: Fernanda B. Carriel e Hilde Silvana P. Cezarini (alunas do Curso de Pedagogia da PUCPR) 


\section{Introdução}

As relações entre a Igreja e o Estado na segunda metade do século XIX caracterizaram-se por um progressivo distanciamento que culminou com a separação definitiva no alvorecer do novo século, ao ser proclamada a República. Apesar do enfraquecimento gradativo do nexo que unia as duas instituições, a maioria do clero e os prelados da Igreja foram, ao que tudo indica, apanhados de surpresa tanto pelo advento do novo regime quanto pelo Decreto que formalizou a separação. Inúmeros autores trabalharam 0 tema, e a bibliografia apresentada no final do texto, mesmo sem ser exaustiva, o comprova; no entanto, procuraremos defender uma tese que ainda não foi suficientemente pesquisada, que é a seguinte: A Igreja não se dava conta de que, em nível nacional, ao longo dos últimos cinqüenta anos do século, estavam ocorrendo transformações significativas no modo de produção. Somente um membro do clero o percebeu, e fazendo eco à Pastoral de 1890, viu a separação como um grito de autonomia, necessitando, a Igreja, contudo, na sua opinião, para exercer a missão de que se via investida pela Encíclica Rerum Novarum, partir para a realização de uma dupla tarefa: formar a elite e educar o povo. Isso porque "a ignorância não permite ao povo praticar um cristianismo verdadeiro" e a "impiedade política é um resultado lógico da educação racionalista e pagã... das classes dirigentes brasileiras" (JÚLIO MARIA, 1981, p. 122 e 125).

Dividimos este artigo em cinco capítulos, como segue: 1 . procuraremos identificar a forma assumida pelo capitalismo no Brasil na segunda metade do século XIX; 2. traçaremos um mapa das relações que se estabeleceram entre a Igreja e o Estado brasileiro, na época; 3. analisaremos as encíclicas Quanta Cura (com o syllabus) e Rerum Novarum; 4. destacaremos a atuação do padre Júlio Maria e a sua opção pela educação como estratégia de "combate", em um momento de transformações que ocorriam no modo de produção capitalista; 5. verificaremos na Pastoral Coletiva de 1890, a opção pela educação como ação missionária.

I. O Capitalismo do Café: O capitalismo como sistema se desenvolveu nos países mais adiantados da Europa Ocidental a partir do século XV, iniciando sua consolidação no século seguinte, de forma progressiva na Inglaterra, na França, na Holanda, na Bélgica, na Itália, na Alemanha. Trata-se, de acordo com FANFANI (1984, p.17-18), de um sistema econômico que apresenta algumas características fundamentais, tais como:

a) é um regime de atividade econômica justificado e construído por indivíduos que entendem que a vida econômica deve ser organizada por cada indivíduo, em função do lucro máximo pessoal, com o mínimo dispêndio; 
b) é um regime de atividade econômica que, em virtude do seu princípio de organização, tende a eliminar todas as resistências naturais, sociais e humanas que, de algum modo, possam impedilo de atingir o fim do lucro máximo com o menor dispêndio.

Dessa maneira, 1) "exalta o espírito de iniciativa individual e condena todos os princípios ou instituições que o limitam, ou reprimem, favorecendo, por isso, o individualismo; 2) exalta a busca constante de novidades técnicas e institucionais que aumentem o rendimento, independentemente do menosprezo dos diversos valores humanos, sempre que isso não prejudique 0 máximo rendimento, em vista do qual favorece a técnica; 3) combate a validez das limitações, de qualquer natureza, que se oponham à organização da vida em função do rendimento econômico, agregando-se deste modo a uma doutrina fundamentalmente hedonista que, por fim, recai no materialismo; 4) exalta a ordenação da vida pública em função do espírito de iniciativa individual e do progresso técnico contínuo, apoiando-se no liberalismo ou no intervencionismo, mas dando a preferência ao primeiro; 5) sacrifica, do ponto de vista de produtividade seguido pelos dirigentes da atividade econômica, os interesses não produtivos, inclusive os espirituais, dos próprios dirigentes".

Para TAWNEY, na sua obra sobre a religião e a ascensão do capitalismo, este é um:

modo de existência, um sistema no qual predomina o capital, em que os trabalhadores estão separados dos meios de produção e que promove a livre concorrência, a prosperidade dos bancos, o desenvolvimento do crédito, o crescimento da indústria e a unificação de um mercado mundial (1926, p. 22).

Já o francês PIGOU, no seu livro sobre capitalismo e socialismo, afirma que há capitalismo quando "os meios materiais de produção são propriedade de particulares, estão arrendados para particulares ou são utilizados, de acordo com as circunstâncias, para vender com lucro os bens e os serviços para cuja produção contribuem, e quando o trabalhador vende a sua força de trabalho" (1937, p. 6).

lemos o seguinte:

Nos textos de PRZEWORSKI sobre capitalismo e social-democracia,

O capitalismo é uma forma particular de organização social da produção e troca. Baseado em uma avançada divisão do trabalho, é um sistema no qual a produção orienta-se para as necessidades de terceiros, para a troca. Portanto, é um sistema em que mesmo os indivíduos que participam diretamente na transformação da natureza em produtos úteis - os produtos imediatos - não podem sobreviver fisicamente sozinhos. Ademais, o capitalis- 
mo constitui um sistema em que aqueles que não possuem os instrumentos de produção precisam vender sua capacidade de trabalho. Os trabalhadores recebem um salário, que não é um direito sobre qualquer parte do produto específico que geram, mas um meio abstrato de aquisição de quaisquer bens ou serviços. Devem produzir lucros como condição da continuidade de seu emprego (1989, p.23-24).

BOBBIO (1994, p. 141) elenca três elementos que caracterizariam o capitalismo: a) a propriedade privada dos meios de produção, para cuja ativação é necessária a presença do trabalho assalariado formalmente livre; b) sistema de mercado, baseado na iniciativa privada, não necessariamente pessoal; c) processos de racionalização dos meios e métodos diretos e indiretos para valorização do capital e a exploração das oportunidades de mercado para efeito de lucro.

No Brasil, no período que chamamos de colonização direta (Portugal e Espanha), as relações de dominação das Metrópoles sobre a Colônia deramse na forma de exploração "sui generis" tanto da mão-de-obra quanto dos bens naturais ou produzidos, em função da geração e do desenvolvimento do capital mercantil, fato que situa o País no contexto do sistema econômico mundial (Europa Ocidental) que o engloba, enquanto país de capitalismo periférico. Isso coloca o pesquisador diante de um problema ao procurar situar as relações de produção no Brasil-colônia no contexto de uma caracterização de capitalismo industrial, com burguesia, etc. No entanto, ao nos darmos conta de que a produção econômica é "determinada pelo exterior, pelos interesses comerciais da metrópole, cujo Estado detém o monopólio das importações e das exportações e que as mercadorias geradas na colônia são apropriadas pela metrópole por meio do comércio colonial" (OLIVEIRA, 1985, P. 58), fica mais claro o entendimento de como se processavam as relações de produção no Brasil colonial.

O sistema de capitanias hereditárias e de sesmarias gerou no Brasil o latifúndio, a grande propriedade, cuja forma mais típica, segundo RIBEIRO, é a "fazenda", que funcionou como "instituição social básica e como modelo de organização empresarial capitalista que, reunindo o domínio da terra e o monopólio da força de trabalho, permitia produzir artigos determinados para o mercado mundial, a fim de obter lucros pecuniários" (1970, p. 227), daí que ela se distingue da grande propriedade feudal, pois basicamente não desenvolve a produção para a subsistência, mas orienta-se para o mercado. No entanto, como as relações de produção são escravistas e funcionam na base da relação senhor-escravo (em que as relações se estabelecem sob o crivo da autoridade fundada no fato de que o senhor era o proprietário do homem que possuía a força de trabalho), a "fazenda", no período colonial, é uma unidade de produção com características muito específicas, uma simbiose de unidade 
econômica pré-capitalista e, ao mesmo tempo, capitalista, fenômeno que pode ser compreendido somente no contexto de uma análise que leve em consideração o caráter de exploração colonial do País, como acabamos de ver. Por isso, a economia brasileira no período colonial não se explica por si mesma, mas exige uma abordagem que contemple um tipo de relação centro/periferia, pois quem domina a produção e seu funcionamento é a metrópole, como diz OLIVEIRA (op. cit., p. 56). No entanto, segundo LEITE (1943, vl. VI, p. 78), nas "fazendas" mantidas pelos jesuítas, a relação senhor/ escravo se fundava no respeito mantido pelos escravos à força "mágica" que eles atribuíam aos jesuítas, no trato com as coisas sagradas e com a divindade, em especial a cura e, também, como afirma EISENBERG (2000, p. 80), o "privilégio de conversar com os espíritos", à semelhança dos piagas indígenas.

Após a Proclamação da Independência e as pressões da Inglaterra para que cessasse o tráfico de escravos, as "fazendas" irão adquirir, em particular no Oeste de São Paulo e Zona da Mata, em Minas Gerais, um estatuto de unidades econômicas com peculiaridades que a aproximavam mais das características do capitalismo, tal como vimos nos autores utilizados para conceitualo. Mesmo conservando-se como grandes propriedades rurais de monocultura, as fazendas deverão trocar a mão-de-obra escrava pela força de trabalho assalariada.

Nesse período, o engenho de cana de açúcar cede lugar à fazenda de café, utilizando técnicas inovadoras de cultivo e beneficiamento. De acordo com NOGUEIRA (1984, p. 72), "o café questionou o regime de trabalho escravo e impôs sua transformação", fazendo com que surgisse, especialmente na Região Sudeste do Brasil, uma "nova elite urbanizada que começou a disputar o poder com as demais frações da classe social dominante e a imprimir a marca dos seus interesses, idéias e costumes no conjunto da sociedade". Dessa maneira, foi a partir do "impulso da produção e da exportação do café e da abolição do tráfico de escravos que se iniciou no Brasil o movimento de acumulação capitalista" (MESQUIDA, 1984, p. 69), fazendo com que ao lado dos plantadores de café aparecessem as camadas médias urbanas, constituídas sobretudo de pequenos comerciantes, intelectuais e profissionais liberais, modificando o mapa econômico e da estratificação social brasileira durante a segunda metade do século XIX.

As relações sócio-econômicas entre o fazendeiro, plantador de café, e a mão-de-obra também mudam, pois o trabalho assalariado colocará em questão a relação de compadrio, de clientelismo, de proteção, que gerou a prática do favor, da compensação, do "toma lá, dá cá" que, de certa forma, se cristalizaria nas relações que se estabeleceram entre senhor e escravo/camponês, no mundo rural, estudadas por Victor Nunes Leal, na obra Coronelismo, Enxada e Voto.

Alem disso, o fazendeiro deixa a fazenda para morar na cidade de 
onde administra a sua propriedade rural. O pagamento de salário e a racionalização da cultura do café contribuem para enfraquecer os laços de proteção que caracterizam a sociedade senhorial. No meio urbano, o fazendeiro gerencia o capital financeiro obtido com a venda do café, aplicando o excedente.

Dessa maneira, o trabalhador perde o contato direto com o proprietário da fazenda, agora gerida "in loco" pelo capataz, sente-se isolado, desprotegido, procurando, por meio das manifestações espirituais, compensar a perda da proteção. O capitalismo sincrético, mágico, de culto aos santos protetores, em particular aquele vivido nas capelas das fazendas, nas procissões, etc., preenche parcialmente 0 vazio.

Nas cidades, as irmandades e as confrarias, ao oferecerem calor comunitário, mantêm, de certa forma, o catolicismo sincrético, mágico, laico.

Assim, percebe-se que a "fazenda" de café, em particular no Oeste paulista e na Zona da Mata, em Minas Gerais, se caracterizava pelo fato de ser uma propriedade individualizada que utilizava mão-de-obra assalariada e empregava técnicas racionais de produção, com o objetivo de satisfazer 0 mercado e obter o maior lucro possível, o que a consagra como uma unidade econômica de produção de tipo capitalista, de um "capitalismo agrário".

\section{Relações Conflituosas: Igreja e Estado no Segundo Império:}

A Igreja no Brasil não percebia as transformações que estavam ocorrendo no modo de produção e insistia em manter as mesmas relações com o Estado e com a sociedade civil, que caracterizavam a sua forma de operar no quadro do sistema econômico pré-capitalista, típico de uma sociedade senhorial e de uma relação política colonial.

A relação entre Cristianismo e Estado remonta ao ano 313, quando 0 Imperador Constantino transformou o cristianismo, um movimento subversivo, em Igreja, institucionalizando-o e fazendo dele um aliado. As invasões dos bárbaros, que fragmentaram o Império romano, colocaram em questão, em particular na baixa Idade Média, a relação entre cristianismo e Estado. Esta simbiose somente se revigora na alta idade média, em especial a partir da criação da Ordem de Cristo e da instituição do padroado.

$\mathrm{O}$ regime do padroado consistiu no fato de que a Igreja delegava a uma instituição ou a um indivíduo a jurisdição sobre um determinado território para que nele fosse promovida a propagação da fé cristã.

Em Portugal, devido à ação na luta contra os mouros, o rei recebeu do Papa jurisdição sobre determinados territórios, o que se consagrou como um padroado régio, isto é, autoridade para escolher bispos, criar dioceses, além de dispor do beneplácito, que lhe concedia a autoridade para aprovar previamente as determinações emanadas da Santa Sé.

Em 1456, quarenta anos depois de ter assumido o cargo de grãomestre da Ordem de Cristo, o Infante D. Henrique obteve um segundo padroado: autonomia para organizar a ação da Igreja nos territórios que viessem a ser 
descobertos ou conquistados, o que irá se confirmar por meio da bula Praeclara caríssima, emitida pelo Papa Júlio III, em 1551, que subordinava a Igreja às autoridades civis nas terras descobertas por Portugal. Um ano antes, em 1550, o Rei havia feito com que o Papa fundisse a Ordem de Cristo à Coroa. Com isso, o rei de Portugal iria ser também o grão-mestre da Ordem de Cristo (DAEHNDARDT, 1993, p. 136).

Dessa forma, a Igreja passou a legitimar as tomadas de posse de novos territórios e as conquistas da Coroa portuguesa. Percebe-se, portanto, que a presença do religioso nas expedições exploradoras, de conquista e de colonização no Brasil, estava alicerçada nos direitos adquiridos pelo rei de Portugal de manter os dois poderes, o civil e o religioso, sobre o território ocupado.

A vigência do padroado, um verdadeiro regalismo, permaneceu intocada após a proclamação da Independência (durante quatro anos D.Pedro I tentou obter da Santa Sé o direito de Padroado, pois ele não era grão-mestre da Ordem de Cristo, nem Rei de Portugal. Somente em 1827, foi enviada uma bula concedendo o direito de padroado ao Estado imperial), unindo Igreja e Estado no Brasil, e fazendo dos bispos funcionários estatais encarregados do culto religioso, dependentes do Estado tanto para o próprio sustento quanto para a manutenção das atividades eclesiásticas. Até mesmo as leis originadas da Santa Sé careciam do placet imperial para adquirirem validade (isso a partir de 1843, quando o Estado brasileiro declarou que o direito de padroado era da competência do imperador, sem dependência da concessão pontifícia (JÚLO MARIA, 1981, p. 68). Trata-se, portanto, de uma dependência total do Estado: política, econômica e jurídica, pois a decisão última era do Ministério da Justiça e, em casos mais graves, do próprio Imperador, o qual não exercia um poder religioso sobre a Igreja, mas um direito de governo, que lhe era atribuído pelo regime do padroado. Assim, na qualidade de "funcionários públicos", os membros do clero realizavam uma atividade religiosa nitidamente "burocrática", até porque a própria Igreja enquanto aparelho eclesiástico, encontrava-se enfraquecida, pois o clero regular era pouco numeroso, expulsas que foram as ordens religiosas no período pombalino. A expulsão das ordens religiosas brandiu um duro golpe no catolicismo ortodoxo, clericalizado, e fez brotar do solo brasileiro um catolicismo laico, heterodoxo, sincrético, mágico, popular. Quando as ordens regulares vão, pouco a pouco, retornando, deparam-se com a proibição de receber noviços.

Se isso ocorria com o clero regular, o clero secular encontrava-se num estado deplorável, sob o ponto de vista eclesiástico: "muitos sacerdotes vivem em concubinato, praticam a simonia, dedicam-se a atividades economicamente rentáveis e são relapsos nos serviços religiosos não lucrativos...Interessam-se mais pelas atividades políticas, por meio das quais galgam os postos eclesiásticos ou fazem uma carreira junto ao governo, rele- 
gando o trabalho pastoral", escrevia D. Macedo Costa, em 1874 (MACEDO COSTA, 1982, p. 48).

Encontramos, no período, duas igrejas: uma, clerical, burocrática, pastoralmente debilitada e, outra, laica, ativa, popular. Esta, cultuava os santos e se expressava por meio das confrarias e irmandades e das lideranças leigas (ermitões e beatos que se dedicavam à vida ascética e perambulavam pelo interior, rezando, benzendo, batizando, vistos pelo povo como homens santos). Os leigos realizam festas relgiosas, procissões, lideravam as novenas, as rezas do terço, as ladainhas. Tratava-se de uma "igreja" de "muita reza e pouca missa, muito santo e pouco padre", de um catolicismo mágico, "carismático" (no sentido weberiano), com efeitos de natureza meteorológica (reza para que chova ou faça sol, etc.), terapêutica (cura por meio da reza ou das benzeduras), divinatória, e que não necessita do sacerdote: qualquer pessoa pode ser portadora da "gratia infusa".

A rigor, para a elite dirigente/dominante tal forma de religiosidade era necessária, pois "além de não precisar manter um aparato eclesiástico desenvolvido, continuamente gerando crises pela resistência que poderia opor, pela defesa da ortodoxia católica, tal forma de religiosidade permitia que em torno de um único código religioso, por sinal maleável, se agregassem variadas expressões de religiosidade, conforme as classes sociais, contribuindo assim para manter a unidade social e moral"(LORENZETTI, 1998, p. 29-30). Acrescente-se a isso o fato que as representações religiosas desse catolicismo popular reforçavam as relações sociais em vigor, na medida em que as "relações de aliança entre o devoto e o santo (estimuladas pelos agentes religiosos leigos) é o resultado do trabalho do imaginário sobre a realidade das relações sociais de dominação pessoal. Assim como o camponês se submete ao senhor, que se representa como seu aliado e protetor, ele se submete ao seu santo protetor do céu: as relações entre o homem impotente e os santos poderosos do céu correspondem às relações entre o camponês e o senhor" (OLIVEIRA, 1985, p.128).

Observamos que desde a colonização, o Estado utiliza e submete a Igreja para que esta legitime 0 exercício da hegemonia. Na realidade, para desempenhar essa função, bastava um aparelho eclesiástico fracamente estruturado, pois "a doutrinação religiosa era desnecessária, senão inconveniente. Tal fato deixa claro porque o governo imperial sempre quis manter o controle sobre o aparelho eclesiástico" (LORENZETTI, Op.cit., p. 30). Essa afirmação é corroborada por OLIVEIRA, quando observa que nesse contexto fica patente que:

o paradoxo do catolicismo como religião oficial do Estado imperial não é uma simples "sobrevivência" do passado colonial, mas uma das condições necessárias à manutenção da ordem social senhorial. O Estado imperial precisa do aparelho eclesiástico para manter a unidade nacional (Op. cit., p. 165). 
Quando se fala em unidade nacional, fala-se no sentido sócio-econômico da manutenção de uma camada social senhorial e de suas relações de produção, pois era ela quem dava sustentação política ao regime. Era necessário haver uma articulação permanente e sólida entre a base econômica, a sociedade política e a sociedade civil, articulação costurada pela presença e pela ação do aparelho religioso e as representações que este introduzia no imaginário popular, em particular as relações de lealdade, fundadas na proteção em troca de serviços prestados, e no compadrio, os quais, para o camponês, refletiam sua relação com os protetores celestiais.

As transformações que ocorrem no modo de produção capitalista no Brasil na segunda metade do século XIX colocam em questão o sistema senhorial, tanto a sua base econômica quanto a superestrutura. A fazenda, assumindo a forma de unidade de produção capitalista, como já foi visto nesse artigo, coloca em xeque todo o tipo de relação pré-capitalista ou identificada com esse capitalismo sui generis praticado no Brasil, com as características de país de capitalismo periférico. $\mathrm{O}$ trabalhador, agora assalariado, perde a proteção do senhor que passa a servisto como patrão. Mesmo as suas relações com a terra mudam, pois os instrumentos de trabalho assumem uma racionalidade que antes não possuíam. Tudo isso culmina numa crise do imaginário religioso que produz tensões sociais (Canudos, Contestado, etc.) e chama a atenção e a intervenção da Igreja, reprimindo as manifestações, agora conflituosas, do imaginário popular. O clero, contudo, não percebe que:

quanto mais o intelectualismo (eclesiásstico) reprime a crença na magia, "desencantando" assim os fenômenos do mundo, e estes perdem seu sentido mágico, somente "são" e "acontecem", mas nada "significam, tanto mais cresce a urgência com que se exige do mundo e da "condução da vida, como um todo, que estejam ordenados segundo um "sentido. (WEBER, p. 345-346).

O "sentido" ao qual Weber se refere, tem a ver com o modo de produção capitalista, ou, ao menos, com um certo "espírito" capitalista, que tudo racionaliza.

A Igreja brasileira, alertada pela Encíclica Quanta Cura (1864), começa a perceber que alguma coisa está mudando em nível mundial. Sente, ao mesmo tempo, que as suas relações com o Estado se deterioram. Fazendo eco às condenações do syllabus, volta as suas baterias contra as confrarias e irmandades, onde se praticava um catolicismo popular, laico, sincrético, sendo essas associações a seu ver, locais prediletos da maçonaria a qual, na opinião dos bispos, incorporava os "ismos" que haviam sido alvo da condenação da Santa Sé.

Foi nesse contexto que surgiu a "Questão Religiosa", em 1872, colo- 
cando frente a frente o Estado e a Igreja, e debilitando ainda mais as já tênues relações entre as duas instituições, culminando, finalmente, com o ato de separação, no alvorecer da República.

3. A Espada de São Pedro: A Carta Encíclica de 8 de dezembro de 1864, do Papa Pio IX, dirigida aos Patriarcas, Primazes, Arcebispos e Bispos que estiverem na graça e na comunhão da Sé Apostólica, é um documento de alerta e de condenação "às iníquas tramas dos homens que, espumejando suas confusões como as ondas encapeladas do mar e prometendo liberdade, quando na realidade, eram escravos do mal, trataram de destruir, com suas opiniões capciosas e escritos perniciosos, os fundamentos da religião católica e da sociedade civil"( p. 4). Por isso, "condenamos as horrendas opiniões que, com grande prejuízo das almas e detrimento da sociedade civil, hoje em dia impera, erros que não só se opõem à Igreja Católica, à sua doutrina de salvação e direitos venerados, mas também à lei natural e eterna de Deus, inscrita em todos os corações, da mesma forma que à reta razão; erros dos quais derivam quase todos os demais" (p. 4-5).

Quais seriam esses erros? Em primeiro lugar, o "naturalismo", isto é, a idéia de que a sociedade civil "se constitua e governe sem preocupar-se em nada com a religião, como se ela nem existisse, ou, pelo menos, sem fazer distinção alguma entre as religiões falsas e as verdadeiras" (p. 5).

O segundo erro, decorrente do primeiro, é a "liberdade de consciências e de cultos", não se apercebendo aqueles que a defendem que estão pregando, segundo a Epístola número cinco, de Santo Agostinho, as "liberdades de perdição".

Desses dois erros, digamos, originários, decorrem os "principais erros de nossa época, notados nas alocuções consistoriais, nas encíclicas e outras letras apostólicas do Nosso Santíssimo Padre, o Papa Pio IX" (p. 15). Sua Santidade, fazendo uso da "espada de São Pedro" e utilizando o syllabus, ataca desde o panteísmo, o naturalismo, o racionalismo, o latitudinarismo, 0 liberalismo, até o socialismo, o comunismo, as sociedades secretas, as sociedades bíblicas, as sociedades clérico-liberais. A rigor, as entidades que não estavam atreladas ao catolicismo oficial, e as principais concepções de mundo do século XIX.

Com o documento oficial nas mãos, os bispos irão engajar a igreja brasileira, em um duplo movimento de reorganização e fortalecimento do aparelho eclesiástico e de ataque aos "ismos" condenados pela Encíclica e pelo Silabo. A reorganização e o fortalecimento do aparelho eclesiástico são operacionalizados por meio de: a) um retorno ao centro de irradiação da hegemonia religiosa e política da Igreja, a Santa Sé, em Roma (não se trata ainda da "romanização", mas de um movimento que levará ao processo de romanização); b) uma campanha cerrada contra a maçonaria, o liberalismo, o positivismo, o comunismo, e as associações de expressão popular da fé, como 
as confrarias e irmandades, movimento estudado, em particular, por Riolando AZZI ("O catolicismo popular no Brasil, Petrópolis, Vozes, 1978; "O movimento brasileiro de reforma católica durante o século XIX", REB, fascículo 135, 1974) e Pedro Ribeiro de OLIVEIRA (Op. cit., 1985).

4. Júlio, o porta-voz do Leão: A proclamação da República, em 1889, porá fim a sessenta e sete anos de monarquia e, ao mesmo tempo, aproximará o Brasil, no que diz respeito à forma do sistema político, dos demais países do Continente. O Brasil, a exemplo dos Estados Unidos da América, será, juridicamente, uma federação republicana, sob o regime democrático, isto é, de soberania popular, segundo a visão de mundo liberal. Esta segue a célebre fórmula de Montalembert, retomada por Cavour: Uma igreja livre num estado livre. Por isso, o decreto de 7 de janeiro de 1890, estabelece a separação das duas instituições. Dois meses e meio depois, no dia 19 de março de 1890, os onze bispos católicos no Brasil assinam uma Pastoral Coletiva, redigida, ao que tudo indica, por D. Macedo Costa que, alguns meses mais tarde, apresenta, também, o documento intitulado "Alguns pontos de reforma na Igreja do Brasil".

Na Pastoral Coletiva do Episcopado Brasileiro, os signatários afirmam que a Igreja "não cessa de acentuar a distinção entre os dois poderes e de proclamar a independência da sociedade civil na órbita das suas atribuições temporais...Assim, se a Igreja se mostra extremamente zelosa de sua independência nas coisas espirituais, nela encontra também o Estado o mais extremo propugnador de sua autonomia e de seus direitos nas coisas temporais"( PASTORAL COLETIVA, p. 23). E, após reconhecer que o "Brasil não é mais uma potência católica" (p. 37), interrogam: "o que fazer neste caso concreto, neste novo regime, neste novo modus vivendi que nos é imposto pela força das circunstâncias, no período conturbado e incerto que vamos atravessando?' $\mathrm{E}$, respondem: "apreciar a liberdade da Igreja em si, e a liberdade tal qual nos é reconhecida pelo decreto; apossados dessa liberdade...fazer votos e esforços para que ela se complete e se torne efetiva; cumprir com ânimo resoluto, firme... os nossos deveres cristãos na nova era que se inaugura para o Cristianismo católico no nosso caro Brasil"(p. 37). Finalmente, vendo-se livres de um fardo, o peso do padroado, "uma proteção que nos abafava" (p.38), pretendem permanecer "um em Jesus Cristo, para a reforma dos nossos costumes públicos, para o levantamento moral do nível da nossa civilização aos olhos das outras nações, para a glória daquele Senhor Onipotente, árbitro supremo delas, que as eleva ou as abate conforme a retidão dos seus juízos".

Foi, precisamente, no contexto da Proclamação da República e da separação dos "dois poderes" que Júlio César de Morais Carneiro, advogado formado na Faculdade Direito de São Paulo, promotor público em Mar de Espanha, Minas Gerais, resolve, após ficar viúvo, retirar-se para o seminário de Mariana e preparar-se para o sacerdócio. Ordenado em 1891, adotou o 
nome de Júlio Maria. Desta data até 1895, Padre Júlio Maria percorrerá os Estados das regiões Sul e Sudeste realizando conferências de esclarecimento e de aquecimento da fé, baseado, em especial, na Encíclica Rerum Novarum, do Papa Leão XIII, elaborada logo após a sua posse.

Quando Leão XIII tomou posse, as medidas tomadas por Pio IX "tinham feito da Santa Sé o centro espiritual da Igreja Católica, numa escala jamais atingida, mesmo no apogeu do poderio econômico e político dos papas na Idade Média" (LORENZETTI, Op. cit., p. 37). Nesta encíclica, o Papa procura orientar o clero a buscar nas massas populares católicas, em vias de obterem o direito de voto, "um contraponto para a política anticlerical praticada pela maioria dos governos" (Ibid., p 37), reconhecendo ao mesmo tempo, a situação em que se encontrava a massa trabalhadora, explorada pelas relações de produção capitalistas. Leão XIII reconhece a propriedade privada como direito natural e divino, pois "Deus concedeu a terra a todo o gênero humano para a gozar, porque Deus não a concedeu aos homens para que a dominassem confusamente todos juntos, até porque dividida em propriedades particulares, a terra não deixa de servir à utilidade comum de todos...De tudo isso resulta que a propriedade particular é plenamente conforme à natureza"(Rerum Novarum, p. 09-10). Ao mesmo tempo, defende o trabalho, a divisão da sociedade entre os que possuem e os que não têm propriedades, o trabalho assalariado, características do capitalismo agrário: “Quem os não tem (os produtos do campo), supre-os pelo trabalho, de maneira que se pode afirmar, com toda a verdade, que o trabalho é o meio universal de prover as necessidades da vida, quer ele se exerça em terreno próprio, quer em alguma arte lucrativa cuja remuneração, apenas, sai dos produtos múltiplos da terra, com os quais ela se comuta" (p. 10).

Júlio Maria percebeu, com clareza, que o país vivia um momento importante de "acertos" no modo de produção, cujos reflexos foram a Proclamação da República, a separação da Igreja do Estado e a política econômica do governo republicano. A pastoral coletiva lhe dava um referencial teórico oficial e a Rerum Novarum lançava luz sobre as questões relacionadas com 0 modo de produção. Dessa maneira, Júlio Maria irá pregar contra o "despotismo do capital que deverá se sujeitar à lei da equidade". Para ele, era fundamental que a Igreja exigisse do capital "não a caridade, mas a justiça a quem não tem direito ao trabalho", pois assim estaria "dignificando o trabalhador" (JULIO MARIA, op. cit., p. 121). Percebendo o perigo do homem se tornar um gorila amestrado, conclama a Igreja a levar "os supremos postulados da consciência às fábricas, onde a máquina absorve o homem, não lhe deixando tempo senão de aperfeiçoar a raça dos animais" (Ibidem, p. 121). Fazendo eco ao Papa Leão XIII, reconhece o regime fundado na igualdade, na liberdade, na democracia a qual, segundo Júlio Maria, a Igreja deverá convidar "francamente ao banquete social do evangelho, transfigurando-a no crisol da fé para 
que incorpore todas as classes à grande massa à qual compete hoje o predomínio que já não pode pertencer às dinastias, aristocracias ou burguesias" (p. 121). Na sua opinião, a igreja brasileira ainda "não aceitou praticamente os ensinos do papa. O clero vive separado do povo... O clero contenta-se com uma certa aristocracia de devotos...sua atividade quase que se resume nisto - festa para os vivos e pompas fúnebres para os mortos. O clero brasileiro não tem nenhum valor político e social..... que nos falta, hoje? Uma união com o povo e a resolução para o combate" ( p. 123 e 124). E, quais serão as armas a serem empregadas neste combate?

\section{A educação como escudo e lança, ou o combate dos soldados de} Cristo na terra do café: No livro "Hegemonia Norte-amenicana e educação protestante no Brasil", afirmamos que "a educação em nenhum momento ocupou lugar de destaque no Brasil imperial. O espaço reservado à instrução limitava-se à formação dos quadros necessánios à manutenção do regime". Dizemos, ainda, que o movimento republicano deu à educação do povo um peso que ela não tinha possuído até então, já que, para os republicanos, a democracia se realizaria e se desenvolveria via educação popular, pois a democracia num regime monárquico, aristocrata, excludente e exclusivista, significaria a liberdade". Por isso, a educação do povo era, para os republicanos, um "meio, enquanto o objetivo perseguido era a liberdade" e, como escreve Alberto Salles, "quem diz liberdade, diz instrução, escola luz". Para Salles, "a escola era o instrumento privilegiado da ação revolucionária - a revolução deveria começar pela educação" (MESQUIDA, 1994, p. 82-83).

Proclamada a República, os líderes do partido republicano acionaram os seus intelectuais, atribuindo-lhes a tarefa de diagnosticar a situação da "instrução" e tomar decisões a respeito das ações a serem desenvolvidas. Nos primeiros anos de governo republicano, tiveram início as reformas, seja para dotar os conteúdos programáticos de matérias que atendessem às necessidades do regime e do modo de produção, seja para adotar métodos pedagógicos "modernos" que superassem o método jesuítico (dedutivo) fundado na ratio studiorum, ainda dominante. Exemplos disso, são as reformas Benjamim Constant e as levadas a efeito em São Paulo, particularmente nos cursos que deveriam formar os educadores do novo regime (Escola Normal), como demonstramos no trabalho acima citado.

Pio IX havia tomado medidas no sentido de reorganizar o aparelho eclesiástico. Dessa maneira, a função de Núncio Apostólico, até então exercida por diplomatas leigos, torna-se "uma função exclusiva dos bispos e antigos supeniores das ordens religiosas; as casas-mãe das ordens religiosas são transferidas para Roma, para que a Santa Sé pudesse promover uma articulação das frentes de ação" (LORENZETTI, op.cit., p. 39). Ao mesmo tempo, preocupado em reconstituir "ambientes cristãos" pelo fato de estarem os católicos vivendo em um mundo em processo de secularização, a Igreja vê-se responsável pelo ensino dos católicos. Assim, "na medida em que a instrução generalizava-se e era assumida pelos Estados, com uma orientação "secularizada", o clero católico, com apoio explícito da 
Santa Sé, passa a construir toda uma rede de estabelecimentos de ensino, como parte de suas atividades pastorais" (Ibid. p. 40). Segundo AUBERT (1975, p. 130), essa rede de estabelecimentos de ensino, paralela ou antagônica ao ensino oficial, incluía em meados dos anos de 1880, universidades na Bélgica, na Irlanda, na França e nos Estados Unidos. Esse modelo de magistério pastoral é transplantado para todos os países com presença católica, como forma de garantir ou recuperar a hegemonia social.

O padre Júlio Maria observa que, em 1885, o "ensino estava de tal sorte paganizado" que o próprio imperador resolvera advertir o Ministério do Interior e Obras Públicas, responsável pela educação, sobre o estado em que se encontrava a instrução no império (JÚLO MARIA, op.cit., p.100). Para o padre Júlio Maria, a situação do país era caótica porque a educação era materialista, até porque a Igreja não exercia a influência que deveria exercer. Era, portanto, urgente "educar o povo para assegurar a prosperidade da nação". O próprio Papa, em uma carta enviada aos arcebispos e bispos do Brasil, em 1899, exulta com a presença de novas ordens religiosas que se fazem presentes no Brasil, e que "fundarão e dirigirão colégios", com a finalidade de combater em duas frentes: a elite e 0 povo. Para a elite uma missão educativa; para o povo uma educação missionária. O combate não será empreendido pormeio da violência, mas pormeio da persuasão (Rerum Novarum, p. 24 e Pastoral Coletiva de 1890, p. 35).

Júlio Maria e os Bispos reformadores, signatánios da pastoral coletiva, de 1890, tinham uma visão bíblico-teológica do "divini magisteri" da Igreja. Assim, se expressa a Pastoral: "O ensino da igreja será para todos a regra imediata de fé, e quem não ouvir a igreja, disse Jesus, segundo o Evangelho de Mateus, 18.17, e Lucas 10.16, seja tido como pagão e publicano, pois quem a ouve, a mim me ouve" (p. 31). Por isso, "Ide e ensinai a todas nações, e eis que estarei convosco todos os dias até o fim dos séculos" (p. 31). Portanto, na medida em que "a Igreja tem nos lábios a sílaba fulgurante, o Verbo de Deus, o seu primeiro poder é 0 magistério" (p.31).

Convencida de que o combate pela recuperação da hegemonia, nesses novos tempos, será persuasivo e deverá se realizar no nível da consciência, a Igreja católica brasileira, dos primeiros anos da República, propõe-se a criar uma nova sociedade por meio do "ensino autêntico e da prática segura da religião", pois, na sociedade e pela sociedade, o homem aprende tudo. Ele é "um ente ensinado".

No entanto, de acordo com Luiz Antonio Cunha, a presença da Igreja no ensino superior aberto aos leigos, era incipiente, senão nulo, pois o governo federal, na primeira República, proibia a criação de universidades particulares. Alem disso, a Igreja "estabeleceu primeiro as bases de um ensino secundário" (CUNHA, 1986, p. 316). Na realidade, desde 1805, já não existe ensino superior católico aberto a leigos, quando os franciscanos fecharam o curso de filosofia do convento de Santo Antonio, no Rio de Janeiro.

A chegada de ordens educadoras no Brasil, a partir da década de 1890, irá contribuir para que a Igreja cumpra a missão de que, segundo os bispos 
signatários da Pastoral, se achava investida pelo próprio Cristo, e inicie o combate para restaurar a hegemonia cultural que deteve durante séculos. As Pastorais Coletivas de 1900 e de 1915, em particular a última, irão acentuar o fato de que o ensino deverá ser privilegiado pelos seus pastores nas suas paróquias. Ensino de todos os níveis, para alcançar a sociedade global, elite e povo: Uma educação missionária e uma missão educativa. Aquela, com a finalidade de: a) construir, no povo, uma consciência cidadã (Rerum Novarum, p. 29), agora que o direito ao voto começa a se universalizar, b) resgatar, por meio das escolas paroquiais, do ensino primánio e do ensino secundánio, a ortodoxia católica e, ao mesmo tempo, a centralização do clero como autoridade pastoral.

A missão educativa deveria se efetuar junto à elite, em particular a elite urbana, atraindo-a para as hostes da Igreja e preparando-a para exercer influência junto às autoridades constituídas, a fim de incluir o ensino da religião católica nas escolas públicas, e recuperar a hegemonia social e política abalada com a separação dos "dois poderes", o Estado e a Igreja.

\section{Referências bibliográficas}

AUBERT, R. Nova História da Igreja. Petrópolis: Vozes, 1975.

AZZI, R. 0 catolicismo popular no Brasil. Petrópolis: Vozes, 1978.

AZZI, R. 0 episcopado do Brasil frente ao catolicismo popular. Petrópolis: Vozes, 1977.

AZZI, R. O movimento brasileiro de reforma católica durante o século XIX. In: REB, 135, 1974.

BERGER, M. Educação e dependência. São Paulo: Difel, 1984.

BISPOS. Pastoral Coletiva de 1890. Brasília: UnB, 1981.

BOBBIO, N. Dicionário de política. Brasília: UnB, 1994.

CUNHA, L A. A universidade temporã. Rio de Janeiro: Francisco Alves, 1986.

DAEHNDART, R. A missão templária nos descobrimentos. Lisboa: Nova Acrópole, 1993.

EISENBERG, J. As missões jesuíticas e o pensamento político moderno. Belo Horizonte: UFMG, 2000.

FANFANI, A. Capitalismo, catolicismo, protestantismo. Lisboa: Editorial Áster, 1984. FERNANDES, F. A revolução burguesa no Brasil. Rio de Janeiro: Zahar, 1970. HUBERMAN, L História da riqueza do homem. Rio de Janeiro: LTC, 1980. 
JÚLO MARIA, Pe. A Igreja e a república. Brasília: UnB, 1981.

LEAL, V. N. Coronelismo, enxada e voto. Rio de Janeiro: Forense, 1948.

LEÄO XIII, Papa. Rerum Novarum. São Paulo: Paulinas, 1968.

LEITE, S. História da Companhia de Jesus no Brasil. Rio de Janeiro: Imprensa Nacional, 1943.LOPES, E.M.T. e VEIGA, C.G.(org.). 500 anos de educação no Brasil. Belo Horizonte: Autêntica, 2000.

LORENZETTI, A. A. Romanização do catolicismo e educação no Brasil. Curitiba: PUCPR, Dissertação de Mestrado, 1998, inédita.

LUSTOSA, O. F. Os bispos do Brasil e a imprensa. São Paulo: Loyola, 1983.

MACEDO COSTA, A Memória sobre a situação presente da Igreja no Brasil. In: Cadernos de História da Igreja npo Brasil, vl. 1, São Paulo: Loyola, 1982.

MESQUIDA, P. Hegemonia norte-americana e educação protestante no Brasil. São Paulo: Editeo, 1994.

NOGUEIRA, M. A. As desventuras do liberalismo. São Paulo: Paz e Terra, 1984.

OLVEIRA, P. R. Catolicismo popular e romanização do catolicismo brasileiro. Rio de Janeiro: Cenis, 1976.

OLVEIRA, P. R. Religião e dominação. Petrópolis: Vozes, 1985.

PIGOU, A C. Capitalisme et socialisme. Paris: Gallimard, 1937.

PIO IX, Papa. Quanta cura/syllabus. Petrópolis: Vozes, 1951.

PRZEWORSKI, A. Capitalismo e social-democracia. São Paulo: Ed. Schwarcz,

RIBEIRO, D. As Américas e a civilização. Rio de Janeiro: Civilização Brasileira, 1970.

TAWNEY, R. H. Religion and the rise oh capitalism. Londres: Murray Press, 1926. VAINFAS, R. (org.). Dicionário do Brasil Colonial. Rio de Janeiro: Objetiva, 2000. VIEIRA, D. G. O protestantismo, a maçonaria e a questão religiosa no Brasil. Brasilia: UnB, 1980.

VILAÇA, A. C. O pensamento católico no Brasil. Rio de Janeiro: Zahar, 1975.

WEBER, M. Economia e sociedade. Brasília: UnB, 1999. 